\title{
Penerapan Media Mind Mapping Tipe Network Tree untuk Meningkatkan Hasil Belajar Siswa pada Mata Pelajaran Ilmu Pengetahuan Sosial Madrasah Ibtidaiyah
}

\author{
Listiana Damaya Nursoviani \\ Institut Agama Islam Darussalam (IAID), Ciamis-Jawa Barat \\ Email: damaya.nursovi19@gmail.com \\ Yosep Farhan Dafik Sahal \\ Institut Agama Islam Darussalam (IAID), Ciamis-Jawa Barat \\ Bani Ambara \\ Institut Agama Islam Darussalam (IAID), Ciamis-Jawa Barat
}

\begin{abstract}
This research is motivated by the low learning outcomes of grade 3 students at Madrasah Ibtidaiyah Cidolog on social studies subjects. This is by teaching social studies the teacher always uses conventional and monotonous learning media, while students are asked to memorize information that has been heard from their teacher. While social studies learning is required to develop students' thinking abilities, so students can become active can also solve a problem. In an effort to improve student learning outcomes, researchers used Mind Tree Mapping Network Tree Type. The method used is the Classroom Action Research Method (CAR) model of Kurt Lewin. Data collection techniques used were interviews, observation and tests. After conducting research, the authors conclude that: Student learning outcomes in social studies have increased as in the first cycle that is obtained an average value of 72.7 students with 9 complete criteria and 9 incomplete as many people. Cycle II, the average value of students was 83.6 with 13 students completing criteria and 5 students who were unfinished and Cycle III, 91.3 students with an average criterion of 17 students and 1 student who were incomplete
\end{abstract}

Keywords: Social studies learning, network tree type mind mapping media, learning outcomes

\section{PENDAHULUAN}

Pendidikan menurut kamus besar Bahasa Indonesia merupakan proses pengubahan sikap dan tata laku seseorang atau kelompok orang dalam usaha mendewasakan manusia melalui upaya pengajaran dan pelatihan. (Syah, 2000:10). 
Menurut Undang-Undang Sistem Pendidikan Nasional Nomor 20 Tahun 2003, "Pendidikan adalah usaha sadar dan terencana untuk mewujudkan suasana belajar dan proses belajar mengajar agar siswa secara aktif mengembangkan potensi untuk memiliki kekuatan spiritual keagamaan, pengendalian diri, kepribadian, kecerdasan, akhlak mulia, serta keterampilan yang diperlukan dirinya, masyarakat, bangsa dan negara".

Belajar merupakan suatu perubahan dalam tingkah laku, di mana perubahan itu dapat mengarah kepada tingkah laku yang lebih baik, tetapi juga ada kemungkinan mengarah kepada tingkah laku yang lebih buruk. Belajar merupakan suatu proses yang tidak dapat dilihat dengan nyata proses itu terjadi didalam diri seseorang yang sedang mengalami belajar (Ngalim, 2009: 85).

Ilmu pengetahuan social (IPS) merupakan integrasi dari berbagai cabang ilmu-ilmu social, seperti sosiologi, sejarah, geografi, ekonomi, politik, hukum, dan budaya. Ilmu Pengetahuan Sosial dirumuskan atas dasar fenomena sosial yang mewujudkan satu pendekatan interdisipliner dari aspek dan cabang-cabang ilmu sosial (sosiologi, sejarah, geografi, ekonomi, politik, hukum, dan budaya). ( Trianto, 2011:171). Menurut Sapriya (2006: 4) IPS bagi siswa SD/MI berguna untuk mengenal konsep-konsep yang berkaitan dengan kehidupan masyarakat dan lingkungannya.

IPS juga memiliki tujuan utama yaitu diharapkan peserta didik memiliki kemampuan dasar untuk berpikir logis, kritis, rasa ingin tahu, inquiri, memecahkan masalah dan memiliki keterampilan dalam kehidupan sosial. Oleh karena itu, seorang guru dituntut harus mampu merancang suatu pembelajaran semaksimal mungkin agar bisa mencapai tujuan pembelajaran.

Hasil belajar menurut Gagne \& Briggs (1979:51) adalah kemampuankemampuan yang dimiliki siswa sebagai akibat perbuatan belajar dan dapat diamati melalui penampilan siswa (learner performance). Dalam dunia Pendidikan, terdapat bermacam-macam tipe hasil belajar yang telah dikemukakan oleh para ahli antara lain Gagne (1979:51) mengemukakan lima tipe hasil belajar, yaitu intelektual skill, cognitive strategy, verbal information, motor skill, dan attitude.

Reigeluth (1983) berpendapat bahwa hasil belajar atau pembelajaran dapat juga dipakai sebagai pengaruh yang memberikan suatu ukuran nilai metode (strategi) alternative dalam kondisi yang berbeda. Ia juga mengatakan secara spesifik bahwa hasil belajar adalah suatu kinerja (performance) yang diindikasikan sebagai suatu kapabilitas (kemampuan) yang telah diperoleh. Hasil belajar suatu dinyatakan dalam bentuk tujuan (khusus) perilaku (unjuk kerja). (Suprihatiningrum, 2016: 37). 


\section{BESTARI}

Vol. 16, No. 2, 2019

p-ISSN 1907-1337; e-ISSN 2807-6532

Madrasah IbtidaiyahCidolog adalah salah satu institusi pendidikan yang didalamnya mengajarkan Ilmu Pengetahuan Sosial sebagai bahan ajar. Madrasah IbtidaiyahCidolog sudah menggunakan Kurikulum 2013 (Kurtilas) tetapi sebagian kelas masih menggunakan Kurikulum Tingkat Satuan Pendidikan (KTSP) yaitu kelas 3 dan kelas 6 Madrasah IbtidaiyahCidolog Kecamatan Cidolog telah di tetapkan Kriteria Ketuntasan Minimal (KKM) untuk mata pelajaran Ilmu Pengetahuan Sosial di kelas 3 sebesar 73. Namun, kenyataan yang terjadi di lapangan hasil belajar Ilmu Pengetahuan Sosial yang diperoleh siswa masih di bawah KKM yaitu dengan rata-rata nilai 71.3. Dari 18 orang siswa di kelas 3 ada 10 siswa yang masih mendapatkan nilai di bawah KKM dan 8 siswa yang sudah mencapai KKM. (Sumber : hasil wawancara dengan wali kelas 3 Madrasah IbtidaiyahCidolog, 16 Maret 2018).

Dalam proses pembelajaran, guru selalu menggunakan media pembelajaran yang konvensional dan monoton, dan dalam pembelajaran IPS ini siswa diminta untuk menghafal suatu informasi yang sudah didengar dari gurunya. Sedangkan pembelajaran IPS dituntut harus megembangan kemampuan berfikir siswa supaya siswa bisa menjadi aktif juga dapat memecahkan suatu permasalahan. Hal itu akan menyebabkan siswa merasa jenuh, kurang antusias dan cenderung bosan dalam mengikuti kegiatan belajar mengajar.

Untuk mengatasi permasalahan pembelajaran agar dapat meningkatkan hasil belajar, salah satu strategi alternatif yang dapat digunakan untuk mengaktifkan siswa dikelas adalah dengan menggunakan media Mind Mapping Tipe Network Tree. Dipilihnya Media pembelajaran ini karena dapat meningkatkan pemahaman siswa, karena peta konsep merupakan cara belajar yang mengembangkan proses belajar bermakna, dapat meningkatkan keaktifan dan kreatifitas berpikir siswa, dan akan memudahkan siswa dalam belajar.

Dalam bukunya Buzan (2010: 13), menyatakan bahwa peta konsep secara otomatis akan mengaitkan informasi baru dengan informasi yang sudah tersimpan dalam otak. Dengan kalimat lain peta konsep dapat diartikan sebagai media yang berupa ilustrasi grafis yang digunakan untuk menghubungkan konsep-konsep ke dalam konsep-konsep lain pada kategori yang sama. Dalam (Septiana, 2011:14).

Dengan demikian, masalah pokok dalam penelitian ini, yaitu: Bagaimana upaya peningkatan hasil belajar siswa melalui Media Mind Mapping Tipe Network Tree pada mata pelajaran Ilmu Pengetahuan Sosial Pokok Bahasan Jenis-jenis Pekerjaan di kelas 3 Madrasah IbtidaiyahCidolog Kecamatan Cidolog Kabupaten Ciamis? 


\section{LANDASAN TEORI}

\section{Pembelajaran Ilmu Pengetahuan Sosial}

Pembelajaran ilmu pengetahuan sosial (IPS) di sekolah dasar sangat penting artinya dalam mempersiapkan sumber daya manusia dengan ilmu pengetahuan dan tekhnologi yang tinggi semenjak dini. Hal ini yang menjadi hambatan selama ini dalam pembelajaran IPS adalah disebabkan kurang profesionalismenya guru dalam menyampaikan pelajaran, mereka jarang menggunakan alat peraga dan sumber belajar, sehingga kurang menarik minat belajar siswa, dan pada gilirannya prestasi belajar kurang memuaskan. Singkatnya pembelajaran IPS selama ini kurang aplikatif pada kejadian sehari-hari yang ada di lingkungan sekitarnya. (Zainal, 2004:77).

Ilmu pengetahuan sosial (IPS) merupakan salah satu mata pelajaran yang diberikan mulai dari SD/MI/SDLB sampai SMP/MTs/SMPLB. IPS mengkaji seperangkat peristiwa, fakta, konsep dan generalisasi yang berkaitan dengan isu sosial. Pada jenjang SD/MI mata pelajaran IPS memuat materi Geografi, Sejarah, Sosiologi, dan Ekonomi. Melalui mata pelajaran IPS, peserta didik diarahkan untuk dapat menjadi warga negara indonesia yang demokratis, dan bertanggung jawab, serta warga dunia yang cinta damai. (BSNP, 2006:174).

Ilmu pengetahuan sosial (IPS) merupakan integrasi dari berbagai cabang ilmu-ilmu sosial, seperti sosiologi, sejarah, geografi, ekonomi, politik, hukum, dan budaya. Ilmu Pengetahuan Sosial dirumuskan atas dasar fenomena sosial yang mewujudkan satu pendekatan interdisipliner dari aspek dan cabang-cabang ilmu sosial (sosiologi, sejarah, geografi, ekonomi, politik, hukum, dan budaya). ( Trianto, 2011:171).

Menurut Sapriya (2006: 4) IPS bagi siswa SD/MI berguna untuk mengenal konsep-konsep yang berkaitan dengan kehidupan masyarakat dan lingkungannya. IPS atau studi social merupakan bagian dari kurikulum sekolah yang diturunkan dari isi materi cabang-cabang ilmuilmu social: sosiologi, sejarah, geografi, ekonomi, politik, antropologi, filsafat, dan psikologi social.

Pendidikan Ilmu Pengetahuan Sosial adalah penyederhanaan disiplin ilmu sosial, ideologi negara dari disiplin ilmu lainnya serta masalahmasalah sosial terkait yang diorganisasikan dan disajikan secara ilmiah dan psikologi untuk tujuan pendidikan pada tingkat pendidikan dasar dan menengah. (Sapriya, 2006:7).

Berdasarkan uraian diatas dapat disimpulkan bahwa Ilmu pengetahuan sosial adalah ilmu yang mempelajari tentang kemasyarakatan yang didalamnya terdapat cabang ilmu lain seperti sosiologi, geografi, sejarah, hukum dan budaya.

Pendidikan di Indonesia mengklasifikasikan objek kajian yang dipelajari dalam IPS kedalam beberapa tingkatan. Untuk pendidikan 


\section{BESTARI}

Vol. 16, No. 2, 2019

p-ISSN 1907-1337; e-ISSN 2807-6532

tingkat dasar, materi IPS yang dibahas dibatasi dengan hanya mengkaji materi yang bersentuhan dengan sejarah dan geografi atau materi yang bersinggungan langsung dengan lingkungan peserta didik usia SD/MI. Berbeda hal nya dengan pendidikan pada tingkat menengah, objek yang menjadi kajian lebih diperluas dengan beberapa pendekatan yang difungsikan untuk melatih daya nalar peserta didik.(Sapriya, 2009:18).

Ruang lingkup mata pelajaran IPS meliputi aspek-aspek sebagai berikut: (BNSP, 2006:174).

1) Manusia, Tempat dan Lingkungan

2) Waktu, Keberlanjutan dan Perubahan

3) Sistem, Sosial dan Budaya

4) Perilaku, Ekonomi dan Kesejahteraan.

Tujuan utama ilmu pengetahuan sosial ialah untuk mengembangkan potensi peserta didik agar peka terhadap masalah sosial yang terjadi di masyarakat, memiliki sikap mental positif terhadap perbaikan segala ketimpangan yang terjadi, dan terampil mengatasi setiap masalah yang terjadi sehari-hari, baik yang menimpa dirinya sendiri maupun yang menimpa masyarakat. Tujuan tersebut dapat dicapai manakala programprogram pelajaran IPS di sekolah diorganisasikan secara baik. Dari rumusan tujuan tersebut dapat dirinci sebagai berikut (Awan Mutakin, dalam Puskur, 2006:4)

1) Memiliki kesadaran dan kepedulian terhadap masyarakat atau lingkungannya, melalui pemahaman terhadap nilai-nilai sejarah dan kebudayaan masyarakat.

2) Mengetahui dan memahami konsep dasar dan mampu menggunakan metode yang diadaptasi dari ilmu-ilmu sosial yang kemudian dapat digunakan untuk memecahkan masalah-masalah sosial.

3) Mampu menggunakan model-model dan proses berpikir serta membuat keputusan untuk menyelesaikan isu dan masalah yang berkembang di masyarakat.

4) Menaruh perhatian terhadap isu-isu dan masalah-masalah sosial, serta mampu membuat analisis yang kritis, selanjutnya mampu mengambil tindakan yang tepat.

5) Mampu mengembangkan berbagai potensi sehingga mampu membangun diri sendiri agar survive yang kemudian bertanggung jawab membangun masyarakat.

6) Memotivasi seseorang untuk bertindak berdasarkan moral.

7) Fasilitator di dalam suatu lingkungan yang terbuka dan tidak bersifat menghakimi. 
8) Mempersiapkan siswa menjadi warga negara yang baik dalam kehidupannya, dan mengembangkan kemampuan siswa menggunakan penalaran dalam mengambil keputusan pada setiap persoalan yang dihadapinya.

9) Menekankan perasaan, emosi, dan derajat penerimaan atau penolakan siswa terhadap materi pembelajaran IPS yang diberikan.

Di samping itu, juga bertujuan bagaimana sikap siswa terhadap pelajaran berupa: penerimaan, jawaban atau sambutan, penghargaan, pengorganisasian, karakteristik nilai dan menceritakan. (Trianto, 2011:176)

\section{Konsep Mind Mapping Tipe Network Tree}

Model Mind Mapping Tipe Network Tree diperkenalkan oleh tony buzan. Model ini baik digunakan untuk pengetahuan awal siswa atau menemukan alternativ jawaban. (Aqib, 2015:23)

Dalam bukunya Buzan (2010: 13), menyatakan bahwa peta konsep secara otomatis akan mengaitkan informasi baru dengan informasi yang sudah tersimpan dalam otak. Dengan kalimat lain peta konsep dapat diartikan sebagai media yang berupa ilustrasi grafis yang digunakan untuk menghubungkan konsep-konsep ke dalam konsep-konsep lain pada kategori yang sama. Dalam (Septiana, 2011:14)

Peta konsep dikembangkan oleh Tony Buzan tahun 1970-an yang didasarkan pada bekerjanya otak. Otak kita mengingat informasi dalam bentuk gambar, simbol, bentuk-bentuk, suara musik dan perasaan. Otak menyimpan informasi dengan pola dan asosiasi seperti pohon dengan cabang dan rantingnya. Jadi, otak tidak menyimpan informasi menurut kata demi kata atau kolom demi kolom dalam kalimat baris yang rapi seperti yang kita keluarkan dalam berbahasa (De Porter dan Hernacki, 2002), maka untuk dapat mengingat kembali dengan cepat apa yang telah kita pelajari sebaiknya belajar kita meniru bekerjanya otak yaitu seperti pohon dengan cabang dan rantingnya disertai gambar, warna simbol pola dan asosiasi, yaitu dalam bentuk peta konsep/pikiran yang menyerupai pohon. Dengan demikian, proses menyajikan dan menangkap isi pelajaran dalam peta-peta konsep mendekati proses alamiah dalam berfikir. Peta konsep menggunakan pengingat-ingat visual dan sensorik dalam suatu pola dari ide-ide yang berkaitan, seperti peta jalan yang digunakan untuk belajar, mengorganisasikan, dan merencanakan. Peta ini dapat membangkitkan ide ide orisinil dan memicu ingatan dengan mudah, jauh lebih mudah daripada pencatatan tradisional. Oleh karena itu, secara fungsional, peta pikiran diartikan sebagai teknik pemanfaatan keseluruhan otak dengan menggunakan citra visual dan prasarana grafis lainnya untuk membentuk kesan. (Dryden dan Vos dalam Sugiyanto, 2010: 105) dalam (Azmi,2011:46) 


\section{BESTARI}

Vol. 16, No. 2, 2019

p-ISSN 1907-1337; e-ISSN 2807-6532

Berdasarkan beberapa pendapat dapat disimpulkan bahwa Mind Mapping adalah metode pembelajaran yang menjalankan fungsi otak manusia untuk berfikir mengenai informasi yang baru dengan informasi yang sudah diketahui oleh otak manusia.

Menurut Nur (Trianto, 2010: 160), peta konsep ada empat macam, yaitu pohon jaringan (network tree), rantai kejadian (event chain), peta konsep siklus (cycle concept map), dan peta konsep laba-laba (spider concept map).

\section{1) Pohon Jaringan (network tree)}

Dalam peta konsep pohon jaringan, ide-ide pokok dibuat dalam bentuk persegi empat atau bentuk yang lain, sedangkan beberapa kata yang lain dituliskan pada garis-garis penghubung. Garis-garis pada peta konsep pohon jaringan menunjukkan hubungan antara ide-ide itu. Katakata yang ditulis pada garis menunjukkan hubungan antara konsepkonsep. Pada saat mengkonstruksi suatu pohon jaringan, tulislah topik tersebut dan daftarlah konsep-konsep yang berkaitan dengan konsep tersebut (Trianto, 2010: 161)

Peta konsep model Tony Buzan juga termasuk ke dalam jenis peta konsep pohon jaringan. Buzan (2010: 15), menyatakan bahwa peta konsep jenis ini disusun dengan menggunakan foto atau gambar yang diletakkan di tengah kertas mendatar. Gambar pusat kemudian dihubungkan dengan cabang-cabang utama dan menghubungkan cabangcabang tingkat dua dan tiga ke tingkat satu dan dua, dan seterusnya. Garis penghubung dibuat melengkung. Pohon jaringan cocok digunakan untuk memvisualisasikan suatu hiererki, prosedur bercabang, serta menunjukkan informasi sebab-akibat.

Bagan pohon atau pohon jaringan adalah bagan yang visualisasinya menggambarkansuatu proses dari bawah atau dasar yang terdiri dari beberapa akar menuju batang tunggal.cabang-cabang tersebut menggambarkan perkembangan dan hubungan. (Daryanto, 2015:120)

\section{2) Rantai Kejadian (Event Chain)}

Menurut Nur (Trianto, 2010: 161), peta konsep rantai kejadian dapat digunakan untuk memerikan suatu urutan kejadian, langkah-langkah alam suatu prosedur, atau tahapan-tahapan dalam suatu kejadian. Misalnya dalam melakukan suatu eksperimen. Rantai kejadian cocok digunakan untuk memvisualisasikan langkah-langkah dalam suatu prosedur, suatu urutan kejadian, dan memerikan tahapan-tahapan suatu proses.

\section{3) Peta Konsep Siklus (cycle Concept Map)}

Dalam peta konsep siklus rangkaian kejadian tidak menghasilkan suatu hasil akhir. Kejadian akhir pada rantai itu menghubungkan kembali 
ke kejadian awal. Seterusnya kejadian akhir itu menghubungkan kembali ke kejadian awal siklus itu berulang dengan sendirinya dan tidak ada akhirnya. Peta konsep siklus cocok diterapkan untuk menunjukkan hubungan bagaimana suatu rangkaian kejadian berinteraksi untuk menghasilkan suatu kelompok hasil yang berulang-ulang.

\section{4) Peta Konsep Laba-laba (Spider Concept Map)}

Peta konsep laba-laba dapat digunakan untuk curah pendapat. Melakukan curah pendapat ide-ide berangkat dari suatu ide sentral, sehingga dapat memperoleh sejumlah besar ide yang bercampur aduk. Banyak dari ide-ide dan ini berkaitan dengan ide sentral itu na belum tentu jelas hubungannya satu sama lain. Peta konsep laba cocok digunakan untuk memvisualisasikan hal-hal berikut: (a) tidak menurut hierarki, (b) kategori yang tidak pararel; dan (c) hasil curah pendapat." (Trianto, 2010: 163) dalam (Septiana, 2011:15)

\section{Kelebihan Mind Mapping}

Peta konsep dalam pembelajaran dapat memberi manfaat yang beragam, terutama bagi siswa. Manfaat peta konsep tersebut yaitu :

a) Dapat meningkatkan pemahaman siswa, karena peta konsep merupakan cara belajar yang mengembangkan proses belajar bermakna

b) Dapat meningkatkan keaktifan dan kreatifitas berpikir siswa

c) Akan memudahkan siswa dalam belajar

Kelemahan Peta Konsep

Beberapa kelemahan atau hambatan yang mungkin dialami siswa dalam menyusun peta konsep, yaitu :

a) Dalam menyusun peta konsep membutuhkan waktu yang cukup lama, sedangkan waktu yang tersedia di dalam kelas sangat terbatas

b) Siswa sulit menentukan konsep-konsep yang terdapat dalam materi yang dipelajari

c) Siswa sulit menentukan kata penghubung untuk menghubungkan konsep yang satu dengan konsep yang lain dalam (Septiana, 2011: 19)

Langkah-Langkah Mind Mapping

Untuk membuat peta pikiran, guru hendaknya menggunakan bolpoint bewarna dan memulai dari bagian tengah kertas. Kalau bisa, guru menggunakan kertas secara melebar untuk mendapatkan lebih banyak tempat. Langkah-langkah Mind Mapping, diantaranya;

1) Tulis gagasan utamanya di tengah-tengah kertas dan lingkupilah dengan lingkaran, persegi, atau bentuk lain. 


\section{BESTARI}

Vol. 16, No. 2, 2019

p-ISSN 1907-1337; e-ISSN 2807-6532

2) Tambahkan sebuah cabang yang keluar dari pusatnya untuk setiap poin atau gagasan utama. Jumlah cabang-cabangnya akan bervariasi,tergantung dari jumlah gagasan dan segmen. Gunakan warna yang berbeda untuk tiap-tiap cabang.

3) Tuliskan kata kunci atau frase pada tiap-tiap cabang yang dikembangkannya untuk detail. Kata kunci adalah kata-kata yang menyampaikan inti sebuah gagasan dan memicu ingatan anda. Jika anda menggunakan singkatan tersebut sehingga anda dengan mudah segera mengingat artinya selama berminggu-minggu setelahnya.

4) Tambahkan simbol-simbol dan llustrasi-ilustrasi untuk mendapatkan ingatan yang lebih baik.

Peta konsep dapat digunakan sebagai media pembelajaran karena peta konsep merupakan media dengan jenis gambar dua dimensi. Peta konsep merupakan alat mencatat yang kreatif, efektif, dan secara harfiah akan memetakan pikiran (Buzan, 2010:4)

Sebagai suatu media peta konsep cocok digunakan untuk pembelajaran dengan materi yang banyak. Melalui peta konsep materimateri tersebut akan dihubungkan secara inklusif. Penggunaan peta konsep dalam pembelajaran akan memberikan manfaat yang banyak kepada siswa. Dahar (1996: 156-160), mengungkapkan manfaat peta konsep dalam pembelajaran, yaitu menyelidiki apa yang telah diketahui siswa, belajar bagaimana cara belajar, dan sebagai alat evaluasi belajar. dalam (Septiana, 2011:20).

\section{Konsep Hasil Belajar}

Hasil belajar menurut Gagne \& Briggs (1979:51) adalah kemampuankemampuan yang dimiliki siswa sebagai akibat perbuatan belajar dan dapat diamati melalui penampilan siswa (learner performance). Dalam dunia Pendidikan, terdapat bermacam-macam tipe hasil belajar yang telah dikemukakan oleh para ahli antara lain Gagne (1979:51) mengemukakan lima tipe hasil belajar, yaitu intelektual skill, cognitive strategy, verbal information, motor skill, dan attitude.

Reigeluth (1983) berpendapat bahwa hasil belajar atau pembelajaran dapat juga dipakai sebagai pengaruh yang memberikan suatu ukuran nilai metode (strategi) alternative dalam kondisi yang berbeda. Ia juga mengatakan secara spesifik bahwa hasil belajar adalah suatu kinerja (performance) yang diindikasikan sebagai suatu kapabilitas (kemampuan) yang telah diperoleh. Hasil belajar suatu dinyatakan dalam bentuk tujuan (khusus) perilaku (unjuk kerja). (Suprihatiningrum, 2012: 37)

Menurut Dimyati dan Mudjiono hasil belajar merupakan hasil dari suatu interaksi tindak belajar dan tindak mengajar. Dari sisi guru, tindak 
mengajar diakhiri dengan proses evaluasi hasil belajar. Dari sisi siswa, hasil belajar merupakan berakhirnya pengajaran dari puncak proses belajar.

Hasil belajar sangat erat kitannya dengan belajar atau proses belajar. Hasil belajar pada sasarannya dikelompokkan dalam dua kelompok, yaitu pengetahuan dan keterampilan. Pengetahuan dibedakan menjadi empat macam, yaitu pengetahuan tentang fakta-fakta, pengetahuan tentang prosedur, pengetahuan konsep, dan ketrampilan untuk berinteraksi.

Beberapa hasil penelitian menunjukkan bahwa kualitas hasil belajar (prestasi belajar) di duga di pengaruhi pula oleh tinggi rendahnya motivasi berprestasi yang dapat dilihat dari nilai rapor. Untuk menunjukkan tinggi rendahnya atau baik buruknya hasil belajar yang di capai siswa ada beberapa cara. Satu cara yang sudah lazim digunakan adalah dengan memberikan skor terhadap kemampuan atau keterampilan yang dimiliki siswa setelah mengikuti proses belajar tersebut.

Sardiman, (2009:94) menyatakan dengan mengetahui hasil pekerjaan, apalagi kalau terjadi kemajuan, akan mendorong siswa untuk lebih giat belajar. Semakin mengetahui bahwa grafik hasil belajar meningkat maka ada motivasi pada diri siswa untuk terus belajar, dengan suatu harapan hasilnya terus meningkat.

Menurut Uno (2006:35), tujuan pembelajaran biasanya diarahkan pada salah satu Kawasan dari taksonomi pembelajaran. Krathwohl, Bloom, \& Masia (1973) memilah taksonomi pembelajaran dalam tiga Kawasan, yakni Kawasan kognitif, Kawasan afektif dan Kawasan psikomotorik. (Suprihatiningrum, 2012:37)

Berdasarkan uraian diatas dapat disimpulkan bahwa hasil belajar adalah perubahan yang terjadi setelah adanya interaksi antara guru dan siswa yang telah berhasil mencapai apa yang sudah ia pelajari selama pembelajaran.

Hasil belajar siswa dipengaruhi oleh dua faktor utama yakni faktor dari dalam diri peserta didik dan faktor yang datang dari luar diri peserta didik atau faktor lingkungan. Faktor dari dalam diri peserta didik terutama menyangkut kemampuan yang dimiliki peserta didik. Faktor ini besar sekali pengaruhnya terhadap hasil belajar yang akan dicapai. Clark mengungkapkan bahwa hasil belajar peserta didik di sekolah 70\% dipengaruhi oleh kemampuan peserta didik dan 30\% dipengaruhi oleh lingkungan. (Angkowo \& Kosasih, 2007:50)

Ada dua faktor yang mempengaruhi hasil belajar peserta didik, yakni:

Ada lima faktor internal yang mempengaruhi hasil belajar diantaranya kesehatan badan dan panca indera, kecerdasan, minat, motivasi belajar dan bakat. (Slameto, 1995:54). Slameto mengemukakan bahwa kesehatan adalah keadaan baik segenap badan serta semua 


\section{BESTARI}

Vol. 16, No. 2, 2019

p-ISSN 1907-1337; e-ISSN 2807-6532

bagiannya bebas dari penyakit. Kesehatan seseorang dapat berpengaruh pada proses dan hasil belajarnya. (Slameto, 1995:54). Kecerdasan atau intelegensi besar sekali pengaruhnya terhadap kemajuan belajar. Dalam situasi yang sama untuk siswa yang mempunyai intelegensi tinggi akan lebih berhasil dari siswa yang mempunyai intelegensi rendah. (Slameto, 1995:56). Minat sangatlah besar pengaruhnya terhadap belajar karena bila bahan pelajaran yang dipelajari tidak sesuai dengan minat, maka akan mengurangi kesungguhan dalam mengikuti pembelajaran karena tidak ada daya tarik baginya. (Slameto, 1995:57). Motivasi belajar yaitu kondisi belajar terpenting untuk mengarahkan tingkah laku seseorang dalam mencapai tujuan belajar dan hasil belajar yang optimal.(Slameto,1995:57). Bakat adalah sesuatu kecakapan khusus yang dimiliki oleh seseorang, juga merupakan kemampuan seseorang untuk mengembangkan kecakapan-kecakapan tertentu. Dengan demikian, seseorang yang berbakat dalam suatu disiplin ilmu, maka ia akan giat untuk mempelajarinya yang berpengaruh terhadap hasil belajarnya. (Effendi dan Praja, 1993:98)

Faktor Eksternal adalah faktor yang mempengaruhi hasil belajar siswa yang berasal dari luar individu seperti lingkungan sekolah, lingkungan keluarga, dan lingkungan masyarakat. Lingkungan sekolah dapat mempengaruhi belajar siswa, diantaranya yaitu metode belajar, kurikulum, sarana dan prasarana sekolah, waktu, standar pelajaran, relasi guru dengan siswa, disiplin sekolah dan pelajaran. ( Slameto, 1995:54). Lingkungan keluarga sangat mempengaruhi kegiatan belajar. Ketegangan keluarga, sifat-sifat orang tua, demografi keluarga (letak rumah), pengelolaan keluarga, semuanya dapat memberi dampak terhadap aktivitas belajar siswa. Hubungan antara anggota keluarga, orang tua, anak, kakak, atau adik yang harmonis akan membantu siswa melakukan aktivitas belajar dengan baik. Hal ini tentu akan berakibat pula pada hasil belajar siswa. (Syah, 2006:52). Kondisi lingkungan masyarakat tempat tinggal siswa akan mempengaruhi hasil belajar siswa. Lingkungan siswa yang kumuh, banyak pengangguran dan anak terlantar juga dapat mempengaruhi aktivitas belajar siswa, paling tidak siswa kesulitan ketika memerlukan teman belajar, diskusi atau meminjam alat-alat belajar yang kebetulan belum dimilikinya. Dengan kondisi siswa yang seperti ini tentu akan sangat mempengaruhi terhadap hasil belajar siswa. (Syah, 2006:54)

Menurut Suryabrata (1989:142), faktor-faktor yang mempengaruhi hasil belajar digolongkan menjadi tiga, yaitu: faktor dari dalam, faktor dari luar, dan faktor instrumen. Faktor instrumen yaitu faktor yang berhubungan dengan perangkat pembelajaran seperti kurikulum, struktur program, sarana dan prasarana pembelajaran (media pembelajaran), serta guru sebagai perancang pembelajaran. Dalam penggunaan perangkat pembelajaran tersebut harus dirancang oleh guru sesuai dengan hasil yang diharapkan. 


\section{METODE PENELITIAN}

Metode penelitian yang digunakan adalah metode Penelitian Tindakan Kelas (PTK) model Kurt Lewin. Sedangkan teknik pengumpulan data yang digunakan adalah observasi, tes, wawancara. Penelitian ini bertujuan untuk meningkatkan hasil belajar Siswa melalui media Mind Mapping Tipe Network Tree pada mata pelajaran Ilmu Pengetahuan Sosial pokok bahasan Jenis-jenis pekerjaan. Penelitian Tindakan Kelas pada siwa kelas 3 Madrasah IbtidaiyahCidolog Kecamatan Cidolog Kabupaten Ciamis.

\section{HASIL PENELITIAN DAN PEMBAHASAN}

Dari kegiatan yang dilakukan pada siklus pertama yaitu guru belum terlalu mampu menyusun RPP dengan menggunakan media pembelajaran Network Tree. Hal ini diperoleh dari hasil observasi terhadap kemampuan guru dalam menyusun RPP pada siklus I baru mencapai 91.33 dari skor ideal 100. Kekurangannya terletak pada kurangnya penilaian dalam penyusunan RPP.

Dalam proses pembelajaran pada siklus I, ada beberapa hal yang tidak dilaksanakan oleh guru. Maka diperoleh hasil observasi terhadap kemampuan guru dalam mengajar mencapai nilai rata-rata 90.3 dari skor ideal 100.

Dari hasil tes akhir siswa pada siklus I diperoleh hasil belajar siswa mencapai rata-rata 72,7 dari skor ideal 100, pada kisaran 50\% ketuntasan dengan kriteria yang tuntas sebanyak 9 orang siswa dan yang belum tuntas sebanyak 9 orang siswa dari 18 orang siswa. Hal ini dikarenakan siswa masih kurang aktif bertanya, mengajukan pendapat, dan berusaha bekerja sama dalam kelompok.

Pada siklus II guru sudah mampu menyusun RPP yang menggambarkan media pembelajaran Network Tree. Hal ini diperoleh dari hasil ibservasi terhadap kemampuan guru dalam menyusun RPP mencapai nilai rata-rata 92,29 dari skor ideal 100. Akan tetapi masih ada kekurangan-kekurangan yang ditemukan terutama pada sumber belajar yang hanya menggunakan satu sumber belajar saja.

Pelaksanaan pembelajaran pada siklus kedua guru mengalami peningkatan dalam pelaksanaan pembelajaran, ini terlihat dari hasil observasi terhadap penilaian kemampuan guru dalam mengajar yang mencapai nilai rata-rata 92,43 dari skor ideal 100. Namun dalam hal ini masih ada kekurangan diantaranya siswa belum terbiasa mengajukan pertanyaan mengenai materi pembelajaran. Dan guru belum mampu mengkondisikan kelas dengan lebih kondusif. 


\section{BESTARI}

Vol. 16, No. 2, 2019

p-ISSN 1907-1337; e-ISSN 2807-6532

Dari hasil tes akhir siswa pada siklus II diperoleh nilai hasil belajar siswa mencapai nilai rata-rata 83,6 dari skor ideal 100, pada kisaran $72 \%$ ketuntasan dengan kriteria yang mencapai nilai KKM sebanyak 13 orang siswa dan yang belum mencapai nilai KKM sebanyak 5 orang siswa. Berdasarkan hasil tersebut maka hasil tes akhir nilai siswa mengalami peningkatan dari siklus pertama.

Pada siklus III, guru sudah mampu menyusun RPP dengan menggunakan media pembelajaran Network Tree. Hal ini diperoleh dari hasil observasi terhadap kemampuan guru dalam menyusun RPP mencapai nilai rata-rata 95,25 dari skor ideal 100.

Pelaksanaan pembelajaran pada siklus III guru mengalami peningkatan dalam proses pembelajaran, ini terlihat dari observasi penilaian kemampuan mengajar guru yang mencapai nilai rata-rata 94,86 dari skor ideal 100.

Dari hasil evaluasi tes niali akhir, siswa mengalami peningkatan hasil belajar mencapai nilai rata-rata 91,3 dari skor ideal 100. Pada kisaran 94\% ketuntasan dengan kriteria yang mencapai nilai KKM sebanyak 17 orang siswa dan yang belum mencapai nilai KKM sebnayak 1 orang siswa.

Maka hal ini dalam proses pembelajaran IPS melalui media pembelajaran Mind Mapping Tipe Network Tree di kelas III Madrasah IbtidaiyahCidolog Kecamatan Cidolog Kabupaten Ciamis sudah baik dan dapat meningkatkan hasil belajar siswa serta mencapai hasil nilai rata-rat diatas KKM yaitu 73 .

Dari penjelasan diatas dapat disimpulkan bahwa terjadi peningkatan dari siklus I sampai siklus III. Untuk kinerja guru dalam menyusun RPP pada siklus I diperoleh nilai rata-rata 91,33, siklus II diperoleh nilai ratarata 92,29, dan siklus III diperoleh nilai rata-rata 95,3. Sedangkan kemampuan guru dalam mengajar pada siklus I diperoleh nilai rata-rata 90,3, siklus II diperoleh nilai rta-rata 92,43, dan siklus III diperoleh nilai rata-rata 94,86 .

Demikian pula pada hasil belajar siswa pada siklus I yaitu diperoleh nilai rata-rata siswa 72,7 dengan kriteria yang tuntas sebanyak 9 orang dan yang belum tuntas sebanyak 9 orang. Siklus II diperoleh rata-rata nilai siswa 83,6 dengan kriteria yang tuntas sebanyak 13 orang dan yang belum tuntas sebanyak 5 orang. Siklus III diperoleh nilai rata-rata siswa 91,3 dengan kriteria yang tuntas 17 orang siswa dan yang belum tuntas sebanyak 1 orang. 
Grafik peningkatan hasil dari skilus 1 sampai siklus 3

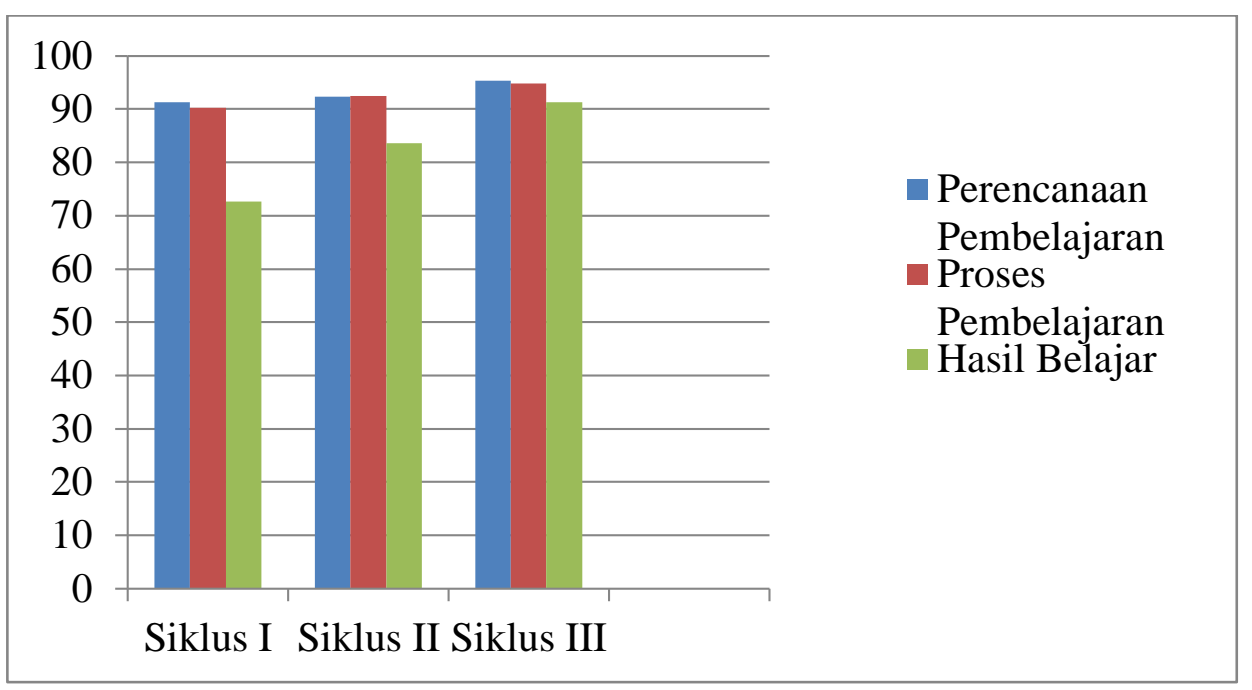

\section{KESIMPULAN}

Berdasarkan hasil penelitian yang telah dideskripsikan pada pembahasan sebelumnya, tentang peningkatan hasil belajar siswa melalui pembelajaran IPS pokok bahasan jenis-jenis pekerjaan dengan menggunakan media pembelajaran Mind Mapping Tipe Network Tree diperoleh data bahwa rata-rata hasil belajar siswa kelas III semester II Madrasah Ibtidaiyah Cidolog Kecamatan Cidolog Kabupaten Ciamis, dalam proses pembelajaran dari siklus I sampai siklus III berhasil meningkatkan hasil belajar siswa melalui berbagai upaya tindakan, untuk itu dapat diambil kesimpulan hal-hal sebagai berikut :

1. Penyusunan perencanaan pelaksanaan pembelajaran (RPP) IPS pokok bahasan jenis-jenis pekerjaan dengan menggunakan media Mind Mapping Tipe Network Tree di kelas III Madrasah Ibtidaiyah Cidolog Kecamatan Cidolog Kabupaten Ciamis, yang dilaksanakan oleh guru mengalami peningkatan, hal itu dilihat dari hasil observasi kinerja guru dalam merencanakan pembelajaran dari siklus I sampai siklus III, pada siklus pertama diperoleh nilai rata-rata 91,33, meningkat pada siklus kedua diperoleh nilai rata-rata 92,29 dan pada siklus ketiga diperoleh nilai rata-rata 95,3.

2. Proses pembelajaran IPS dengan pokok bahasan jenis-jenis pekerjaan dengan menggunakan media Mind Mapping Tipe Network Tree di kelas III Madrasah Ibtidaiyah Cidolog Kecamatan Cidolog Kabupaten Ciamis mengalami peningkatan, hal itu dapat dilihat pada siklus pertama diperoleh nilai rata-rata 90,3, meningkat pada siklus kedua diperoleh nilai rata-rata 92,43 dan siklus ketiga diperoleh nilai ratarata 94,86 . 


\section{BESTARI}

Vol. 16, No. 2, 2019

p-ISSN 1907-1337; e-ISSN 2807-6532

3. Hasil belajar siswa kelas III Madrasah Ibtidaiyah Cidolog Kecamatan Cidolog Kabupaten Ciamis pada mata pelajaran IPS pokok bahasan jenis-jenis pekerjaan menggunakan media pembelajaran Mind Mapping Tipe Network Tree mengalami peningkatan, hal itu dapat dilihat dari hasil evaluasi belajar siswa dari siklus I sampai siklus III, siklus pertama diperoleh nilai rata-rata 72,7 pada kisaran $50 \%$ ketuntasan pada kriteria yang mencapai nilai KKM sebanyak 9 orang siswa dan yang belum mencapai nilai KKM sebanyak 9 orang siswa, meningkat pada siklus kedua diperoleh nilai rata-rata 83,6 pada kisaran $72 \%$ ketuntasan pada kriteria yang mencapai nilai KKM sebanyak 13 orang siswa dan yang belum mencapai nilai KKM sebanyak 5 orang siswa, dan siklus ketiga diperoleh nilai rata-rata 91,3 pada kisaran $94 \%$ ketuntasan dengan kriteria yang mencapai nilai KKM sebanyak 17 orang siswa dan yang belum mencapai nilai KKM sebanyak 1 orang siswa.

\section{DAFTAR PUSTAKA}

Angkowo,R., dan Kosasih, A. (2007). Optimalisasi Media Pembelajaran. Jakarta; PT. Grasindo

Arikunto, Suharsimi. (2006). Penelitian Tindakan Kelas. Jakarta: Bumi Aksara.

Aqib, Zainal. (2009). Penelitian Tindakan Kelas. Bandung; Yrama Widya

Aqib, Zainal. (2015). Model-model, Media, dan Strategi Pembelajaran Konstekstual (Inovatif). Bandung: Yrama Widya

Aunurrahman. (2012). Belajar dan Pembelajaran. Bandung : ALFABETA

BSNP. 2006. Standar Isi standar Kompetensi dasar Kurikulum Tingkat Satuan Pendidikan jenjang Pendidikan Sekolah Dasar. Badan Standar Nasional Pendidikan; Jakarta

Buzan, Tony. (2010). Buku Pintar Mind Map. Jakarta: Gramedia

Dahar, Ratna Wilis. (1996). Teori-teori Belajar. Jakarta; Erlangga

Dimyati \& Mudjiono. (2006). Belajar dan Pembelajaran. Jakarta: PT Rineka Cipta

Daryanto. (2015). Media Pembelajaran. Bandung: PT Sarana Tutorial Nurani Sejahtera

Kanda. (2001). Penelitian Tindakan Kelas. Jakarta; Dirjen dikti proyek Pendidikan guru Sekolah Dasar

Purwanto, Ngalim. (2009). Psikologi Pendidikan. Jakarta. 
Sadiman, Arief S, dkk. (2008). Media Pendidikan Pengertian, Pengembangan, dan Pemanfaatannya. Jakarta; PT Raja Grafindo Persada

Sapriya. (2006). Konsep Dasar IPS. Bandung : UPI PRESS

Sapriya. (2009). Pendidikan IPS. PT. Remaja Rosdakarya. Bandung

Slameto. (1995). Belajar dan Faktor-faktor yang mempengaruhinya.

Bina Aksara, Jakarta

Sudjana, Nana. (2009). Penilaian Hasil Proses Belajar Mengajar.

Bandung: PT Remaja Rosdakarya.

Suprihatiningrum, Jamil. (2016). Strategi Pembelajaran. Yogyakarta: Arruzz Media

Syah, Muhibbin. (2000). Psikologi Pendidikan dengan Pendekatan Baru. Bandung: PT Remaja Rosda Karya

Syah, Muhibbin. (2006). Strategi Belajar Mengajar. Jakarta; Rineka Cipta

Trianto. (2010). Mendesain Model Pembelajaran Inovatif-Progresif Konsep, Landasan, dan Implementasinya pada KTSP. Jakarta; Kencana Prenada Media Group

Trianto. (2011). Model Pembelajaran Terpadu. Jakarta: Bumi Aksara

Usman Effendi dan Praja. (1993). Faktor-faktor yang mempengaruhi Belajar. Bina aksara, Jakarta

Wahab, Rochmat. (2012). Modul Sekolah Dasar. Universitas Yogyakarta. Yogyakarta.

Yuniartin, Titin. (2015). Media Pembelajaran. Ciamis. 